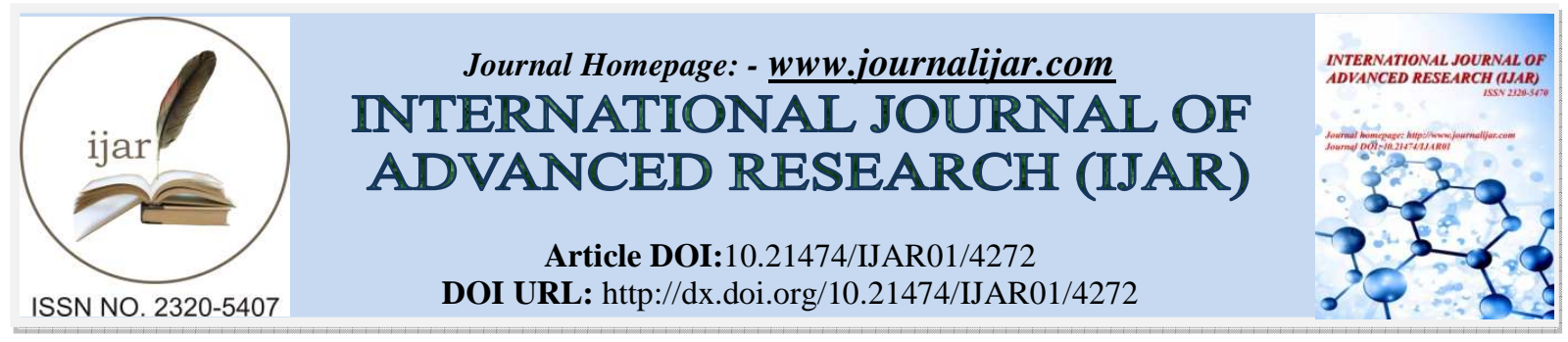

RESEARCH ARTICLE

\title{
EVALUATION OF MICROBIOLOGICAL AND PHYSICOCHEMICAL QUALITY OF BORASSUS AKEASSII FRESH SAP AND FERMENTED SAP (BANDJI) PRODUCED AT BURKINA FASO.
}

Zongo Oumarou, Tapsoba François, Guira Flibert, Zongo Cheikna, Traore Yves and Savadogo Aly*. LABIA/CRSBAN/Département de Biochimie-Microbiologie, UFR-SVT, Université Ouaga 1 Pr Joseph KI-ZERBO, Burkina Faso, 03 BP 7021 Ouagadougou, Burkina Faso.

\section{Manuscript Info}

Manuscript History

Received: 28 March 2017

Final Accepted: 30 April 2017

Published: May 2017

\section{Key words:-}

Borassus akeassii, fresh sap, fermented sap, microbiological and

physicochemical quality, bacteria, yeasts

\begin{abstract}
Palm wines are produced, consumed and appreciated by population of West Africa. Our previous study deal with impact of technological diagram on biochemical and microbiological quality of Borassus akeassii wine produced traditionally in Burkina Faso. This study aims to evaluate the microbiological and physicochemical quality of the fresh and fermented sap from Borassus akeassii. Thirty (30) samples of fresh and fermented sap were collected from traditional producers. The microbiological analysis was carried out using standard microbiology methods and physicochemical parameters were determined by AOAC methods. The analyzes of different samples of sap showed that total count of mesophilic bacteria was between $2.0 \times 10^{6}$ and $1.7 \times 10^{9} \mathrm{CFU} / \mathrm{ml}$; yeasts between $2.2 \times 10^{5}$ and $2.5 \times 10^{8}$ $\mathrm{CFU} / \mathrm{ml}$; lactic acid bacteria (LAB) flora between $1.9 \times 10^{4}$ and $1.8 \times 10^{7} \mathrm{CFU} / \mathrm{ml}$ and acetic acid bacteria (AAB) between $1.3 \times 10^{5}$ and $3.1 \times 10^{7} \mathrm{CFU} / \mathrm{ml}$. Coliforms, Staphylococcus aureus and Salmonella $s p$ strains were found in few samples of fresh sap but absent in the fermented palm sap. Total sugars and Ascorbic acid content of saps ranged from $0.55 \pm 0.05$ to $12.5 \pm 0.1 \%$ (w/v) and $0.78 \pm 0.06$ to 11.01 $\pm 0.22 \%$ (w/v) respectively. The application of good hygiene practices during the collection, selling or packaging of the sap is needed and could improve the quality of palm wine.
\end{abstract}

Copy Right, IJAR, 2017,. All rights reserved

\section{Introduction:-}

The palm trees (family of Arecaceae or Palmeae) are largely widespread in the intertropical areas of Asia, America and Africa (Miège, 1985). They gave innumerable products to the local populations of the developing countries. The sap of the palm trees (one of products) is collected in the whole world by the local populations of the tropical and subtropical areas (Essiamah, 1983; Swing and De Ley, 1977). In Africa, the sap is extracted from the various species of palm trees such as Elaeis guineensis, Raphia hookeri, Phoenix dactylifera, Borassus aethiopum, Cocos nucifera and Borassus akeassii (Ouoba et al., 2012 ; Ziadi et al., 2011 ; Tapsoba et al., 2011 ; Stringini et al., 2009 ; AmoaAwua et al., 2007 ; Sambou et al., 2002 ; Mollet et al., 2000). After the extraction, the crude sap of the palm trees is subjected to a spontaneous fermentation to give an alcoholic drink called palm wine. According to country, the palm wine is known under various names: toddy in India, ети or ogoro in Nigeria, lambanog in Phillipines, taberna in Mexico (Santiago-Urbina et al., 2013; Noll, 2008). In Burkina Faso, the palm wine usually called "bandji" is obtained by natural fermentation of the sap of Borassus akeassii, a new palm tree species identified in south-west 
(Bayton and Ouédraogo, 2009 ; Bayton et al., 2006). The extraction of the sap is practiced twice per days (morning and evening) indifferently of the sex of palm tree following a seasonal mode. The sap is a white liquid milky, flocculent, and characterized by a gas effervescence resulting from the spontaneous fermentation, which testifies to the presence of fermentative micro-organisms (Combet-Blanc, 1997). The methods of tapping palm trees are various but in general, tapping involves perforation of the trunk, insertion of a tube in the hole and collection of the sap in a container (gourd, clay pot, plastic container, glass bottle or calabash) (Dalibard, 1999). According to SantiagoUrbina and Ruíz-Terán (2014), the methods of tapping palm trees depend on the locality but in general, two methods are practiced. In the first method, the sap is obtained from a live standing tree and the second, the tree is felled or cut down before tapping. The sap of the palm tree contains essentially sugar (10-12\% of saccharose), soluble proteins, amino acids, amides, minerals and vitamins (Tiépma et al., 2013; Heller, 1981; Bassir, 1968). Half of the total sugars are fermented during first 24 hours and ethanol content of the fermented palm sap reaches maximum of 5.0 $5.28 \%(\mathrm{v} / \mathrm{v})$ after 48 hours (Sekar and Mariappan, 2005).

Presence of micro-organisms such as yeasts, lactic acid bacteria (LAB), acetic acid bacteria (AAB), enterobacteria, Bacillus spp., Micrococcus spp. and Staphylococcus spp. has been reported (Malonga et al., 1995 ; Atputharajah et al., 1986 ; Okafor, 1975, 1972). Several studies showed that the palm wine results from an alcoholic, lactic and acetic fermentation (Tapsoba et al., 2014; Santiago-Urbina et al., 2013; Ouoba et al., 2012; Stringini et al., 2009; Amoa-Awua et al., 2007; Aidoo et al., 2006; Kadere et al., 2004; Atputharajah et al., 1986; Okafor, 1978). However, the most important role are played by yeasts, LAB and AAB. Generally, palm wine is good for health (Olawale et al., 2010). A balanced administration of fresh and fermented date sap was found to improvise the treatment of hemoglobin deficient anaemic patients and to supplement vitamin-B12 level in the vitamin deficient patients (Debmalya and Mazumdar, 2008). Nutritionally, this drink is a source of sugars and vitamins interesting that complements the daily food intake of consumers (Okafor, 1978; Van Pee and Swings, 1971). It is also involved in traditional ceremonies such as weddings, christenings, funerals, self-help work and as a source of income for rural populations. However, palm wine is traditionally produced by local people. It is diluted frequently with untreated water and directly consumed without any treatment. It is thus necessary to evaluate the quality of this local drink.

\section{Material and Methods:- \\ Sampling:-}

The biological material consisted of ten (10) samples of fresh sap, ten (10) samples of fermented sap after 24 hours of collection and ten (10) samples of fermented sap after 48 hours of collection. Fresh sap is the sap which has been accumulated during the night and collected early the morning. Fermented samples are samples which have been stored and fermenting for additional 1 or 2 days at ambient temperature $\left(25-30^{\circ} \mathrm{C}\right)$ spontaneously. Samples $(500 \mathrm{ml})$ was collected from traditional palm wine tapper in the village of Tiékouna (6 km from Banfora towards Sindou) and Bounouna (located $4 \mathrm{~km}$ the entry of Banfora) in sterile containers. Samples were stored immediately on ice and transported to the laboratory for physicochemical and microbiological analyses.

\section{Physicochemical Analysis:-}

Physicochemical analysis includes $\mathrm{pH}$, total acidity, sugar, Ascorbic acid (Vitamin $\mathrm{C}$ ) and alcohol content. The $\mathrm{pH}$ and total titrable acidity was determined using methods described by Amoa-Awua et al. (2007). The percentage of sugar expressed as degree Brix was measured by refractometry method using a refractometer (METTLER TOLEDO, B/0311) (AOAC, 2000). Vitamin C content was determined by titration method using DIP (2,6Dichlorophénolindophénol) as described by AOAC (1990). Alcoholic content of the samples was determined by densimetry method using hydrostatic balance according to AOAC (2000). The samples were initially degassed with the Ultrasound (BRANSON, 1510E) during 15 minutes then filtered using filter papers (Whatman).Then $30 \mathrm{ml}$ of distilled water are added to $100 \mathrm{ml}$ of filtrate sample. The mixture obtained was distilled with electrochemical distiller (GIBERTINI, B/0303) after addition of $5 \mathrm{ml}$ of the catalyst solution (solution of calcium hydroxide $2 \mathrm{M}$ ) and of some drops of antisolution foams (silicone solution 30\%). After distillation, $100 \mathrm{ml}$ of distillate were collected and the percentage of alcohol (v/v) is read directly using alcohol meter (Super Alcomat).

\section{Microbiological Analysis:-}

The microorganisms were counted according to ISO 7218 (2007): Microbiology of food and animal feed - General rules for microbiological analyzes. The amount of micro-organisms was determined by serial dilutions and spread plate technique was used. Ten milliliter $(10 \mathrm{ml})$ of each sample was diluted with $90 \mathrm{ml}$ of sterile buffered peptone water and well mixed. Successive dilutions of the sap were prepared in screw test tubes and appropriate dilutions were poured into plates on appropriate selective media then enumerated. Aerobic mesophilic flora were counted on 
the PCA agar (Plate Count Agar) incubated at $30^{\circ} \mathrm{C}$ after 24 to 72 hours under aerobic conditions. Sabouraud agar containing Chloramphenicol was used for enumeration of yeasts, the plates were incubated aerobically at $30^{\circ} \mathrm{C}$ for 72 hours. Lactic acid bacteria (LAB) were enumerated on MRS agar (de Man, Rogosa and Sharpe) containing Nystatin (antifungal) which were aseptically added to inhibit the growth of yeasts $(100 \mathrm{mg} / 1)$ and plates incubated at $30^{\circ} \mathrm{C}$ for 4 days. For Acetic acid bacteria (AAB) enumeration, GYC agar (glucose yeast extract and calcium carbonate) were used. Penicillin $(12.5 \mathrm{mg} / \mathrm{l})$ and Nystatin $(100 \mathrm{mg} / 1)$ were added to GYC medium to inhibit LAB and yeast respectively, and plates were incubated at $30^{\circ} \mathrm{C}$ for 5 to 6 days. The total and faecal coliforms were counted on Violet Red Bile Lactose Agar (VRBL) and the plates were incubated for 24 to 48 hours at $37^{\circ} \mathrm{C}$ for total coliforms and $44^{\circ} \mathrm{C}$ for faecal or thermotolerant coliforms. Chapman's agar was used for the enumeration and isolation of Staphylococcus aureus. The plates were incubated aerobically at $37^{\circ} \mathrm{C}$ for 24 to 48 hours. Gram stain, the catalase test and oxidase were performed to confirm the presence of Staphylococcus aureus. The number of colonies counted were expressed as colony forming units (CFU) per ml. Finally, Salmonella and Shigella were tested on Salmonella-Shigella Agar after a pre-enrichment using buffered peptone water and enrichment with Rappaport Vassiliadis Soja buffered. The suspect colonies (uncolourless colonies with or without black center) were selected and purified on Mueller Hinton agar then identify by biochemical tests such as Gram stain, gaz and $\mathrm{H}_{2} \mathrm{~S}$ production, lactose, glucose, urease production, indole, citrate, mannitol, motility.

\section{Statistical Analysis:-}

The data were seized on Excel 2010 and analyzed with software XL STAT 7.5.2. One-way analysis of variance (ANOVA) were used to determine whether there are any significant differences between the various averages of the different parameters. The difference between the averages is significant when $\mathrm{p}<0,05$.

\section{Results and Discussion:- \\ Results of microbiological analyses:- \\ Fresh sap:-}

Microbiological analyses showed that total mesophilic flora of fresh sap varies from $1.6 \times 10^{7}$ to $5.6 \times 10^{8} \mathrm{CFU} / \mathrm{ml}$ and the yeast from $1.2 \times 10^{6}$ to $2.5 \times 10^{8} \mathrm{CFU} / \mathrm{ml}$. LAB are between $5.7 \times 10^{5}$ and $1.8 \times 10^{7} \mathrm{CFU} / \mathrm{ml}$ and $\mathrm{AAB}$ (figure1) between $1.3 \times 10^{5}$ and $3.2 \times 10^{6} \mathrm{CFU} / \mathrm{ml}$. Total coliforms are present in the samples BT2 $\left(6.1 \times 10^{2} \mathrm{CFU} / \mathrm{ml}\right)$, BT4 $\left(5.2 \times 10^{2} \mathrm{CFU} / \mathrm{ml}\right), \mathrm{BB} 1\left(6.8 \times 10^{3} \mathrm{CFU} / \mathrm{ml}\right), \mathrm{BB} 3\left(1.9 \times 10^{4} \mathrm{CFU} / \mathrm{ml}\right)$ and BB5 $\left(4.2 \times 10^{3} \mathrm{CFU} / \mathrm{ml}\right)$. Thermotolerant coliforms were found in the same samples to the number of $1.1 \times 10^{2} \mathrm{CFU} / \mathrm{ml}$ for BT2 sample $4.4 \times 10^{2} \mathrm{CFU} / \mathrm{ml}$ for $\mathrm{BT} 4,5.9 \times 10^{3} \mathrm{CFU} / \mathrm{ml}$ for $\mathrm{BB} 1,6.4 \times 10^{3} \mathrm{CFU} / \mathrm{ml}$ for $\mathrm{BB} 3$ and $1.4 \times 10^{3} \mathrm{CFU} / \mathrm{ml}$ for BB5. The presence of Staphylococcus aureus (figure 2) is noted in samples BT1 $\left(2.1 \times 10^{3} \mathrm{CFU} / \mathrm{ml}\right)$ and BB5 $\left(1.3 \times 10^{5} \mathrm{CFU} / \mathrm{ml}\right)$. Salmonella $s p$ was identified in two samples BB3 and BB5. Fresh sap samples are characterized by the presence of total and faecal coliforms. The samples BT2 and BT4 have a number less than the limit $\left(10^{3} \mathrm{CFU} / \mathrm{ml}\right)$ while the BB1 samples, BB3 and BB5 contain higher numbers. This necessarily indicate fecal contamination of the samples and therefore a poor hygienic quality. Among these samples, two (BB3 and BB5) were contaminated with Salmonella sp and $S$. aureus. Both samples thus exhibit an unsatisfactory microbiological quality (corrupt) with a high risk for consumers. The results of microbiological analyses of fresh sap are presented in table 1.

Table 1:- Results of microbiological analysis of B. akeassii fresh sap (UFC/ml)

\begin{tabular}{|llllllllll|}
\hline Germes & TF & Yeasts & LAB & AAB & CT & CF & S.aureus & Salmonella & Shigella \\
\hline BT1 & $2,2 \times 10^{7}$ & $3,1 \times 10^{6}$ & $1,5 \times 10^{6}$ & $3,1 \times 10^{6}$ & $<10$ & $<10$ & $2,1 \times 10^{3}$ & - & - \\
BT2 & $1,2 \times 10^{8}$ & $1,8 \times 10^{6}$ & $6,2 \times 10^{5}$ & $3,2 \times 10^{6}$ & $6,1 \times 10^{2}$ & $1,1 \times 10^{2}$ & $<10$ & - & - \\
BT3 & $2,7 \times 10^{8}$ & $3,3 \times 10^{6}$ & $1,4 \times 10^{6}$ & $1,3 \times 10^{6}$ & $<10$ & $<10$ & $<10$ & - & - \\
BT4 & $2,9 \times 10^{8}$ & $2,5 \times 10^{8}$ & $1,6 \times 10^{6}$ & $1,5 \times 10^{6}$ & $5,2 \times 10^{2}$ & $4,4 \times 10^{2}$ & $<10$ & - & - \\
BT5 & $1,6 \times 10^{7}$ & $1,5 \times 10^{7}$ & $5,7 \times 10^{5}$ & $1.1 \times 10^{6}$ & $<10$ & $<10$ & $<10$ & - & - \\
BB1 & $2,6 \times 10^{8}$ & $2,5 \times 10^{7}$ & $3,5 \times 10^{6}$ & $4,8 \times 10^{5}$ & $6,8 \times 10^{3}$ & $5,9 \times 10^{3}$ & $<10$ & - & - \\
BB2 & $5,6 \times 10^{8}$ & $2,4 \times 10^{6}$ & $1,8 \times 10^{7}$ & $5,5 \times 10^{5}$ & $<10$ & $<10$ & $<10$ & - & - \\
BB3 & $1,9 \times 10^{8}$ & $1,2 \times 10^{6}$ & $1,6 \times 10^{7}$ & $1,9 \times 10^{6}$ & $1,9 \times 10^{4}$ & $6,4 \times 10^{3}$ & $<10$ & + & - \\
BB4 & $4,7 \times 10^{8}$ & $2,7 \times 10^{6}$ & $1,7 \times 10^{7}$ & $1,3 \times 10^{5}$ & $<10$ & $<10$ & $<10$ & - & - \\
BB5 & $2,4 \times 10^{7}$ & $1,4 \times 10^{6}$ & $2,1 \times 10^{6}$ & $2,9 \times 10^{5}$ & $4,2 \times 10^{3}$ & $1,4 \times 10^{3}$ & $1,3 \times 10^{5}$ & + & - \\
\hline
\end{tabular}

$\mathrm{TF}=$ Total Flora; $\mathrm{LAB}=$ Lactic Acid Bacteria; $\mathrm{AAB}=$ Acetic Acid Bacteria; S. aureus= Staphylococcus aureus $; \mathrm{TC}=$ Total Coliforms; FC= Faecal Coliforms; + = presence; - = absence 
Several studies have reported the presence of TC, FC and pathogens in the palm wine. Indeed, Ogbulie et al. (2007) isolated in palm wine indicators of fecal contamination (E. coli). Similarly, Tapsoba et al. $(2011 ; 2014)$ have shown presence of S. aureus and coliforms in palm wine. Salmonella were identified in the unfermented sap from Raffia in Cameroun (Tiépma et al., 2013). In Nigeria, Obi et al. (2015) have isolated S. aureus and E. coli in fresh sap of Raffia palm.

The presence of coliforms, Staphylococcus aureus and Salmonella sp in samples of fresh sap reveals poor hygienic conditions during the extraction or conditioning of the sap by producers. According to Olawale et al. (2010), these germs could come from the water used in the extraction, or to wash the container used for the collection of the sap in order to dilute sap to increase their income. They might also come from a manual contamination of the collector or the environment (Tapsoba et al., 2014). Insects attracted by the sweet sap can also constitute a source of contamination. Acetic acid bacteria are illustrated in figure 1

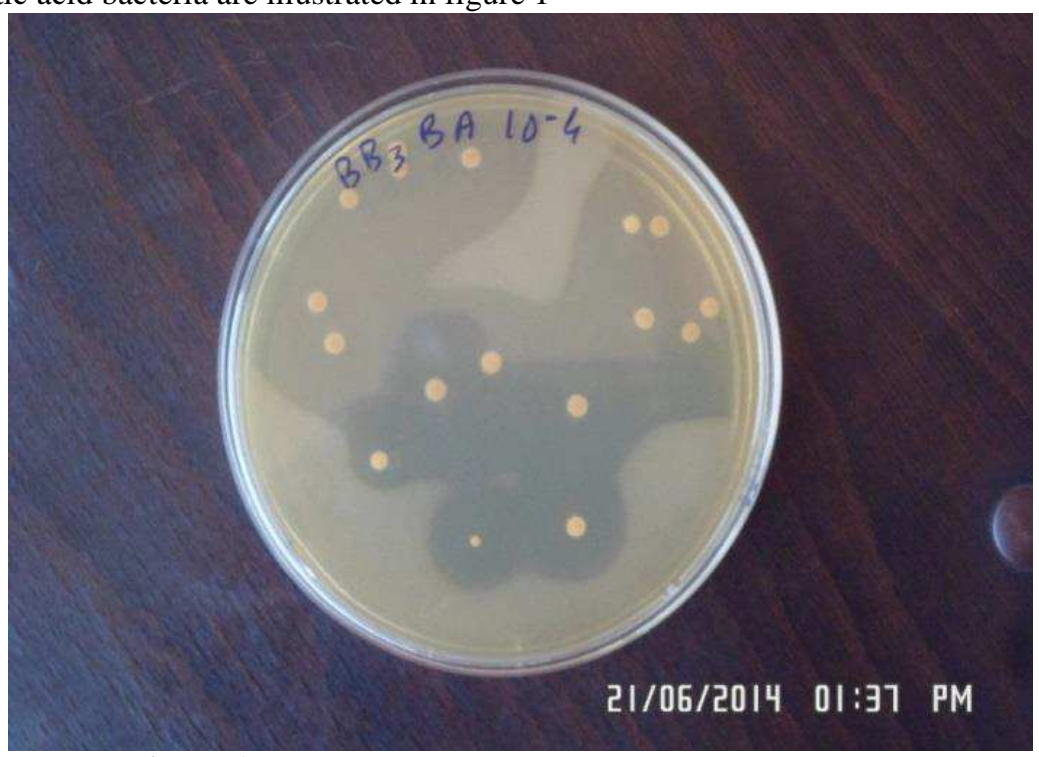

Figure 1:- Colonies of Acetic acid bacteria on GYC Agar

\section{Fermented sap:-}

Total flora of fermented sap after 24 hours of collection was between $1.5 \times 10^{7}$ and $1.7 \times 10^{9} \mathrm{CFU} / \mathrm{ml}$. The yeast flora is between $2.2 \times 10^{6}$ and $1.3 \times 10^{7} \mathrm{CFU} / \mathrm{ml}$; LAB varies from $1.9 \times 10^{4}$ to $2.1 \times 10^{7} \mathrm{CFU} / \mathrm{ml}$. The number of $\mathrm{AAB}$ varies from $1.6 \times 10^{6}$ to $1.4 \times 10^{7} \mathrm{CFU} / \mathrm{ml}$. Coliforms, Salmonella and Shigella as well as pathogenic staphylococci were absent or not more than 10 units in all samples analyzed. The microbiological quality is satisfactory for the various samples of fermented sap for 24 hours (table 2).

Table 2:- Results of microbiological analysis of B. akeassii fermented sap from 24 hours

\begin{tabular}{|llllllllll|}
\hline Germes & TF & Yeasts & LAB & AAB & CT & CF & S.aureus & Salmonella & Shigella \\
\hline BS6 & $8,5 \times 10^{7}$ & $9,4 \times 10^{6}$ & $1,2 \times 10^{6}$ & $1,6 \times 10^{6}$ & $<10$ & $<10$ & $<10$ & - & - \\
BS7 & $2,1 \times 10^{7}$ & $6,9 \times 10^{6}$ & $1,0 \times 10^{6}$ & $6,5 \times 10^{6}$ & $<10$ & $<10$ & $<10$ & - & - \\
BS8 & $4,2 \times 10^{8}$ & $4,1 \times 10^{6}$ & $1,9 \times 10^{4}$ & $1,4 \times 10^{7}$ & $<10$ & $<10$ & $<10$ & - & - \\
BS1.1 & $1,7 \times 10^{9}$ & $7,2 \times 10^{6}$ & $1,5 \times 10^{6}$ & $7,2 \times 10^{6}$ & $<10$ & $<10$ & $<10$ & - & - \\
BS1.2 & $1,5 \times 10^{7}$ & $4,5 \times 10^{6}$ & $7,2 \times 10^{4}$ & $3,3 \times 10^{6}$ & $<10$ & $<10$ & $<10$ & - & - \\
BS1.3 & $7,1 \times 10^{7}$ & $2,2 \times 10^{6}$ & $1,8 \times 10^{6}$ & $4,4 \times 10^{6}$ & $<10$ & $<10$ & $<10$ & - & - \\
BS1.4 & $2,3 \times 10^{8}$ & $1,3 \times 10^{7}$ & $2,1 \times 10^{7}$ & $3,7 \times 10^{6}$ & $<10$ & $<10$ & $<10$ & - & - \\
BS6.1 & $1,6 \times 10^{9}$ & $9,2 \times 10^{6}$ & $8,9 \times 10^{5}$ & $7,9 \times 10^{6}$ & $<10$ & $<10$ & $<10$ & - & - \\
BS7.1 & $1,2 \times 10^{8}$ & $6,8 \times 10^{6}$ & $9,7 \times 10^{6}$ & $2,7 \times 10^{6}$ & $<10$ & $<10$ & $<10$ & - & - \\
BS5 & $3,4 \times 10^{7}$ & $3,5 \times 10^{6}$ & $6,2 \times 10^{6}$ & $8,3 \times 10^{6}$ & $<10$ & $<10$ & $<10$ & - & - \\
\hline
\end{tabular}

$\mathrm{TF}=$ Total Flora; $\mathrm{LAB}=$ Lactic Acid Bacteria; $\mathrm{AAB}=$ Acetic Acid Bacteria; S. aureus $=$ Staphylococcus aureus $; \mathrm{TC}=$ Total Coliforms; $\mathrm{FC}=$ Faecal Coliforms; + = presence; - = absence

The different samples of fermented sap for 48 hours showed a total mesophilic flora ranging from $2.0 \times 10^{6}$ to $1.5 \times 10^{8} \mathrm{CFU} / \mathrm{ml}$, yeast was between $2.2 \times 10^{5}$ and $3.1 \times 10^{7} \mathrm{CFU} / \mathrm{ml}$ and $\mathrm{LAB}$ between $6.4 \times 10^{4}$ and $4.8 \times 10^{6} \mathrm{CFU} / \mathrm{ml}$. As for $\mathrm{AAB}$, the number varies from $1.1 \times 10^{6}$ to $3.1 \times 10^{7} \mathrm{CFU} / \mathrm{ml}$. We also observed absence of coliforms, S. aureus, 
Salmonella and Shigella in all samples analyzed (table 3). These results indicate that microbiological quality of fermented palm sap was satisfactory. To resume, freshly collected sap presente poor hygienic quality but the saps fermented for 24 hours and those fermented for 48 hours have satisfactory microbiological quality (good hygienic quality).

Table 3:- Results of microbiological analysis of B. akeassii fermented sap from 48 hours.

\begin{tabular}{|llllllllll|}
\hline Germes & TF & Yeasts & LAB & AAB & CT & CF & S.aureus & Salmonella & Shigella \\
\hline S6 & $4,8 \times 10^{6}$ & $2,0 \times 10^{6}$ & $1,0 \times 10^{5}$ & $2,5 \times 10^{6}$ & $<10$ & $<10$ & $<10$ & - & - \\
S7 & $2,0 \times 10^{6}$ & $9,2 \times 10^{5}$ & $1,3 \times 10^{5}$ & $1,1 \times 10^{6}$ & $<10$ & $<10$ & $<10$ & - & - \\
S8 & $1,4 \times 10^{7}$ & $8,6 \times 10^{6}$ & $2,5 \times 10^{5}$ & $3,8 \times 10^{6}$ & $<10$ & $<10$ & $<10$ & - & - \\
S1.1 & $2,1 \times 10^{7}$ & $2,7 \times 10^{6}$ & $1,8 \times 10^{6}$ & $4,3 \times 10^{6}$ & $<10$ & $<10$ & $<10$ & - & - \\
S1.2 & $7,7 \times 10^{6}$ & $4,1 \times 10^{6}$ & $2,4 \times 10^{5}$ & $7,0 \times 10^{6}$ & $<10$ & $<10$ & $<10$ & - & - \\
S1.3 & $1,6 \times 10^{7}$ & $1,5 \times 10^{6}$ & $6,4 \times 10^{4}$ & $1,4 \times 10^{6}$ & $<10$ & $<10$ & $<10$ & - & - \\
S1.4 & $5,3 \times 10^{6}$ & $2,2 \times 10^{5}$ & $8,1 \times 10^{4}$ & $3,9 \times 10^{6}$ & $<10$ & $<10$ & $<10$ & - & - \\
S6.1 & $4.2 \times 10^{7}$ & $5,8 \times 10^{6}$ & $4,3 \times 10^{5}$ & $3,1 \times 10^{7}$ & $<10$ & $<10$ & $<10$ & - & - \\
S7.1 & $1,5 \times 10^{8}$ & $3,1 \times 10^{7}$ & $4,8 \times 10^{6}$ & $2,8 \times 10^{7}$ & $<10$ & $<10$ & $<10$ & - & - \\
S5 & $8,7 \times 10^{6}$ & $1,7 \times 10^{6}$ & $9,4 \times 10^{5}$ & $3,3 \times 10^{6}$ & $<10$ & $<10$ & $<10$ & - & - \\
\hline
\end{tabular}

$\mathrm{TF}=$ Total Flora; $\mathrm{LAB}=$ Lactic Acid Bacteria; $\mathrm{AAB}=$ Acetic Acid Bacteria; S. aureus = Staphylococcus aureus; $\mathrm{TC}=$ Total Coliforms; FC= Faecal Coliforms; + = presence; - = absence

Previous studies have also shown that pathogens found in the sap of palm trees disappeared during the fermentation (Obi et al., 2015; Akinrotoye, 2014; Tiépma et al., 2013; Santiago-Urbina et al., 2013; Adedayo and Ajiboye, 2011). The absence of coliforms and pathogens in fermented sap may be due to the alcohol content and acidity ( $\mathrm{pH}$ between 3 and 4) of the medium (Santiago-Urbina et al., 2013). It could also due to antimicrobial substances (bacteriocins, $\mathrm{H}_{2} \mathrm{O}_{2}$ ) and various organic acids (lactic and acetic acids) produced during the fermentation of the sap by the natural flora (Tapsoba et al., 2011; Akinrotoye, 2014).

Lactic acid bacteria of palm wine control the growth of pathogens such as Enterobacteriaceae by the production of acids and hydrogen peroxide $\left(\mathrm{H}_{2} \mathrm{O}_{2}\right)$ (Santiago-Urbina et al., 2013 ; Naknean et al., 2010 ; Alcántara-Hernández et al., 2010 ; Amoa-Awua et al., 2007). The table 4 presente the mean values of microbiological analysis of sap.

Table 4:- Results of the microbiological analyses means values of the various saps from B. akeassii

\begin{tabular}{|l|l|l|l|}
\hline & Fresh sap & Fermented sap 24h & Fermented sap 48h \\
\hline Germs (CFU/ml) & & & \\
Total flora & $2,2 \times 10^{8}$ & $3,9 \times 10^{8}$ & $2,5 \times 10^{7}$ \\
Yeast & $3,1 \times 10^{7}$ & $6,7 \times 10^{6}$ & $6,0 \times 10^{6}$ \\
LAB & $6,2 \times 10^{6}$ & $4,3 \times 10^{6}$ & $8,8 \times 10^{5}$ \\
AAB & $1,3 \times 10^{6}$ & $5,9 \times 10^{6}$ & $8,6 \times 10^{6}$ \\
TC & $50 \%$ & - & - \\
FC & $50 \%$ & - & - \\
S. aureus & ++ & - & - \\
Salmonella & ++ & - & - \\
Shigella & - & - & - \\
\hline
\end{tabular}

$\mathrm{LAB}=$ Lactic Acid Bacteria; $\mathrm{AAB}=$ Acetic Acid Bacteria; S. aureus = Staphylococcus aureus $; \mathrm{TC}=$ Total Coliforms; $\mathrm{FC}=$ Faecal Coliforms;

Presence $=+; \quad$ absence $=$ - 
The figure 2 show Staphylococcus aureus strain found in fresh sap.

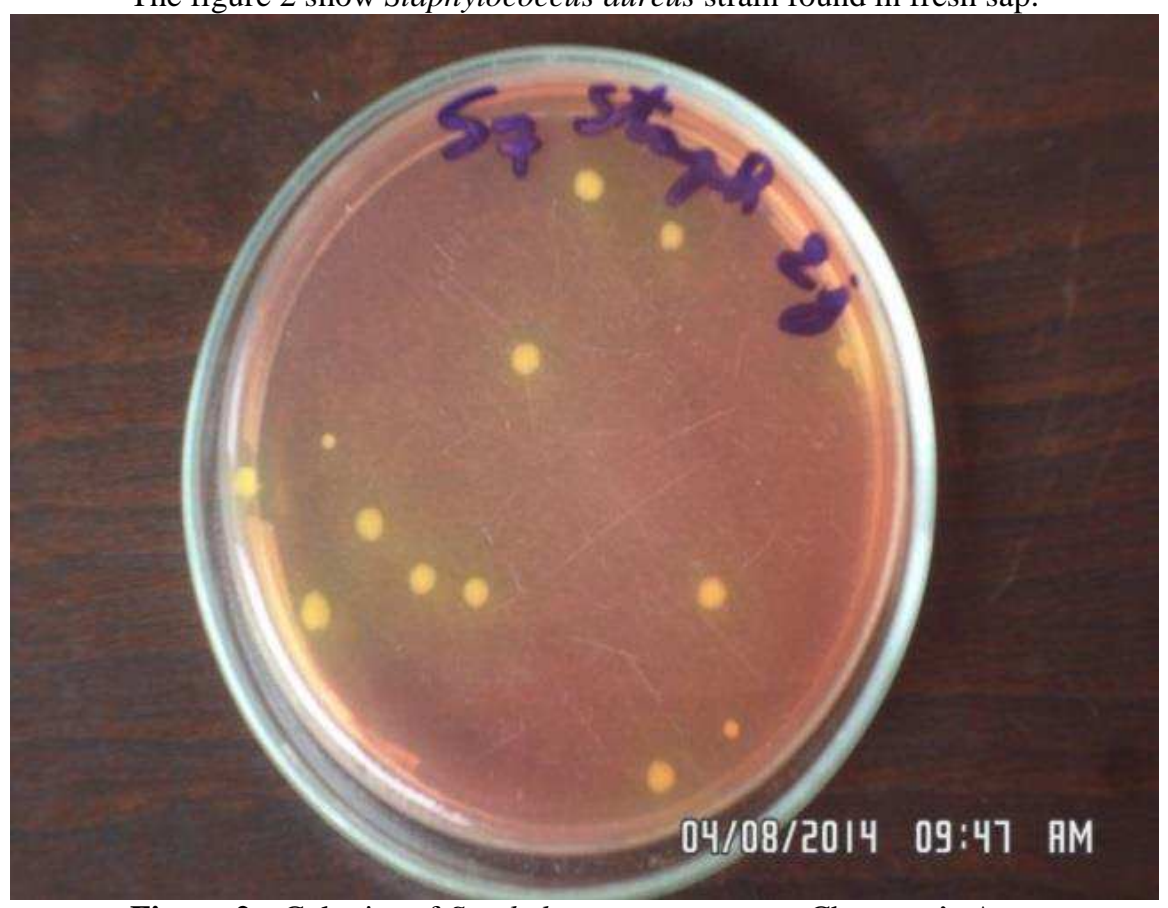

Figure 2:- Colonies of Staphylococcus aureus on Chapman's Agar

\title{
Results of physicochemical Analyses:
}

The physical and chemical quality of Borassus akeassii palm sap was evaluated by the determination of some parameters such as $\mathrm{pH}$, total acidity, total sugars, vitamin $\mathrm{C}$ and the alcohol content.

\begin{abstract}
Analyse of fresh sap:
The $\mathrm{pH}$ of fresh sap samples ranged from $4.05 \pm 0.15$ to $4.86 \pm 0.04$; total acidity from $0.2 \pm 0.01$ to $0.48 \pm 0.03 \%$ (table 5). The total sugar content was between $8.00 \pm 0.00$ and $\pm 12.5 \pm 0.10 \%$ and vitamin $\mathrm{C}$ content between $1.57 \pm$ 0.22 and $11.01 \pm 0.22 \%$. The alcohol content ranged from $0.30 \pm 0.02$ to $2.39 \pm 0.04 \%$. The differences between the averages are meaningful to the different physico-chemical parameters $(\mathrm{p}<0.05)$. The fresh sap is the sap that has been accumulated throughout the night. This sap still has high levels of sugar and vitamin $\mathrm{C}$ despite spontaneous fermentation held. Maintaining these parameters is due to the continuous accumulation of the sweet sap of the palmyra in the fermented or fermenting sap (Amoa-Awua et al., 2007).
\end{abstract}

According to Tapsoba et al. (2014), the pH of different samples of palm wines collected from different producers (fresh sap) was $4.05 \pm 0.61$ to $4.90 \pm 0.10$. These values are similar to our values. This result could be explained by the nature of the fermentation, the kind of palmyra and the sap extraction method. The values of alcohol content are lower than those obtained by Amoa-Awua et al. (2007) and Tapsoba et al. (2014). This result could be explained by several factors such as the nature of fermentation, the type and extraction period of sap, biodiversity of microflora, the collection time and the time between the collection of sap (Figure 3) and analyzes (Ouoba et al., 2012).

However, the alcohol content of fresf sap are close to those obtained by Ouoba et al. (2012) that were 0.30 to $2.73 \%$ (v/v) and Amoa-Awua et al. (2007) between 1.4 and 2.82\% during the first days of sap collection. Some samples of fresh sap has a vitamin C content close to that obtained in Nigeria by Dioha et al. (2009) on the fresh sap of the raffia palm which averaged $8.8 \%$ and $9.01 \%(\mathrm{w} / \mathrm{v})$. Freshly collected sap is an important source of sugars and vitamin $\mathrm{C}$. The table 5 present the results of physicochemical parameters of fresh sap. 


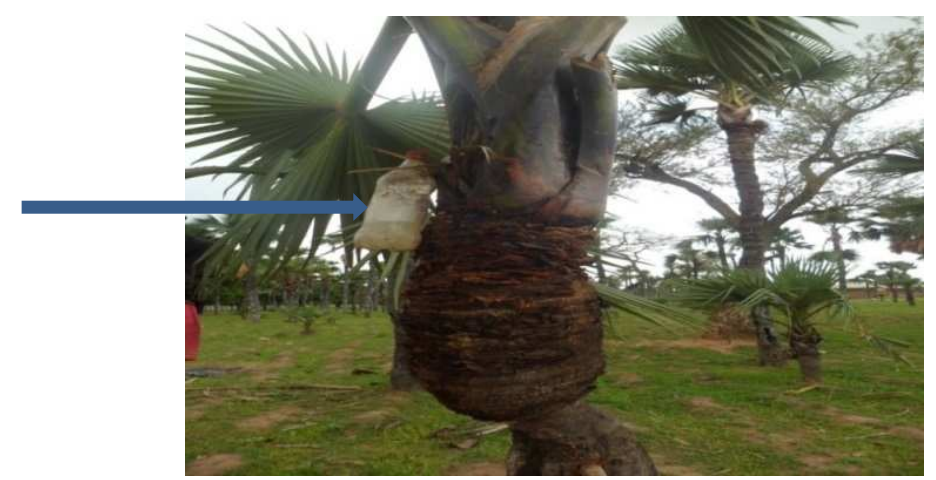

Figure 3:- Technic of collection of Borassus akeassii palm sap by rural peoples

Table 5:- Results of the physicochemical analyses of the fresh sap.

\begin{tabular}{|l|l|l|l|l|l|}
\hline \multirow{2}{*}{ Samples } & \multicolumn{5}{|c|}{ Physico-chemical parameters } \\
\cline { 2 - 6 } & $\mathrm{pH}$ & $\begin{array}{l}\text { Total acidity } \\
\% \mathrm{w} / \mathrm{v}\end{array}$ & $\begin{array}{l}\text { Sugars } \\
\% \mathrm{w} / \mathrm{v}\end{array}$ & $\begin{array}{l}\text { Vitamin C } \\
\% \mathrm{w} / \mathrm{v}\end{array}$ & $\begin{array}{l}\text { Alcohol content } \\
\% \mathrm{v} / \mathrm{v}\end{array}$ \\
\hline BT1 & $4,20 \pm 0,01$ & $0,37 \pm 0,01$ & $9,77 \pm 0,13$ & $7,19 \pm 0,00$ & $1,00 \pm 0,02$ \\
\hline BT2 & $4,08 \pm 0,01$ & $0,47 \pm 0,04$ & $11,80 \pm 0,10$ & $3,59 \pm 0,44$ & $2,08 \pm 0,02$ \\
\hline BT3 & $4,40 \pm 0,02$ & $0,40 \pm 0,01$ & $8,00 \pm 0,00$ & $5,27 \pm 0,12$ & $2,39 \pm 0,04$ \\
\hline BT4 & $4,05 \pm 0,15$ & $0,46 \pm 0,01$ & $9,30 \pm 0,20$ & $1,57 \pm 0,22$ & $0,74 \pm 0,01$ \\
\hline BT5 & $4,50 \pm 0,00$ & $0,37 \pm 0,01$ & $10,10 \pm 0,30$ & $7,86 \pm 0,22$ & $0,38 \pm 0,01$ \\
\hline BB1 & $4,80 \pm 0,03$ & $0,36 \pm 0,02$ & $11,05 \pm 0,05$ & $11,01 \pm 0,22$ & $0,46 \pm 0,02$ \\
\hline BB2 & $4,38 \pm 0,02$ & $0,43 \pm 0,01$ & $10,05 \pm 0,15$ & $2,07 \pm 0,17$ & $2,13 \pm 0,01$ \\
\hline BB3 & $4,86 \pm 0,04$ & $0,20 \pm 0,01$ & $12,50 \pm 0,10$ & $10,34 \pm 0,45$ & $0,54 \pm 0,02$ \\
\hline BB4 & $4,30 \pm 0,02$ & $0,35 \pm 0,01$ & $10,70 \pm 0,10$ & $7,86 \pm 0,22$ & $2,05 \pm 0,02$ \\
\hline BB5 & $4,17 \pm 0,01$ & $0,48 \pm 0,03$ & $10,95 \pm 0,05$ & $8,36 \pm 0,17$ & $0,30 \pm 0,02$ \\
\hline Mean values & $4,37 \pm 0,03$ & $0,39 \pm 0,01$ & $10,42 \pm 0,12$ & $6,51 \pm 0,22$ & $1,20 \pm 0,01$ \\
\hline
\end{tabular}

\section{Analyse of fermented sap:-}

Analysis of fermented sap for 24 hours (Table 6) showed a pH between $3.50 \pm 0.00$ and $3.83 \pm 0.03$ and a total acidity between $0.35 \pm 0.02$ and $0.59 \pm 0.02 \%$. Total sugars varied from $2.40 \pm 0.00$ to $7.1 \pm 0.20 \%$, Vitamin $\mathrm{C}$ from $2.58 \pm 0.11$ to $7.19 \pm 0.22 \%$ and the alcohol content from $1.82 \pm 0.01$ to $4.70 \pm 0.12 \%$. The differences between the averages are meaningful to the different physico-chemical parameters $(\mathrm{p}<0.05)$. The $\mathrm{pH}$ of the fermented sap for 48 hours (Table 7) was between 3.25 \pm 0.01 and $3.51 \pm 0.01$; total acidity between $0.43 \pm 0.01$ and $0.76 \pm 0.01 \%$; the total sugar content ranged from $0.55 \pm 0.05$ to $2.4 \pm 0.1 \%$; the rate of Vitamin $\mathrm{C}$ varies from $0.78 \pm 0.06$ to $4.38 \pm$ $0.11 \%$ and the alcohol level between $3.53 \pm 0.03$ and $6.13 \pm 0.01 \%$. The differences between the averages are meaningful to the different physico-chemical parameters $(\mathrm{p}<0.05)$. Compared to fresh sap, the fermented sap for 24 hours and 48 hours contain low levels of sugars and vitamin $\mathrm{C}$. The fermented sap has higher acidity and alcohol content than fresh sap. These results could be explained by the fermentation activity of the microflora of the sap. Indeed, the natural microflora (bacteria and yeasts) uses vitamins during their growth and continuously converts the sugars into alcohol and / or organic acids. The low $\mathrm{pH}$ of some samples could be due to the intense activity of acidproducing bacteria (LAB and AAB) (Tapsoba et al., 2011). 
Table 6: Physico-chemical parameters of $24 \mathrm{~h}$ fermented palm sap

\begin{tabular}{|l|c|l|l|l|l|}
\hline \multirow{3}{*}{ Samples } & \multicolumn{5}{|c|}{ Physico-chemical parameters } \\
\cline { 2 - 6 } & $\mathrm{pH} / \mathrm{w} / \mathrm{v}$ & $\begin{array}{c}\text { Total acidity } \\
\text { \% } / \mathrm{v}\end{array}$ & $\begin{array}{c}\text { Sugars } \\
\text { \% } / \mathrm{v}\end{array}$ \\
\hline BS6 & $3,55 \pm 0,01$ & $0,39 \pm 0,01$ & $2,47 \pm 0,07$ & $4,15 \pm 0,11$ & $3,72 \pm 0,01$ \\
\hline BS7 & $3,78 \pm 0,02$ & $0,38 \pm 0,01$ & $3,04 \pm 0,34$ & $7,19 \pm 0,22$ & $4,07 \pm 0,03$ \\
\hline BS8 & $3,70 \pm 0,00$ & $0,45 \pm 0,01$ & $2,50 \pm 0,10$ & $3,81 \pm 0,22$ & $3,78 \pm 0,08$ \\
\hline BS1.1 & $3,65 \pm 0,01$ & $0,59 \pm 0,02$ & $3,76 \pm 0,36$ & $6,74 \pm 0,00$ & $4,14 \pm 0,02$ \\
\hline BS1.2 & $3,61 \pm 0,02$ & $0,35 \pm 0,02$ & $2,40 \pm 0,00$ & $3,59 \pm 0,22$ & $3,86 \pm 0,02$ \\
\hline BS1.3 & $3,83 \pm 0,03$ & $0,48 \pm 0,01$ & $4,30 \pm 0,10$ & $4,38 \pm 0,11$ & $4,20 \pm 0,01$ \\
\hline BS1.4 & $3,58 \pm 0,02$ & $0,38 \pm 0,03$ & $3,47 \pm 0,07$ & $4,04 \pm 0,22$ & $3,45 \pm 0,03$ \\
\hline BS6.1 & $3,69 \pm 0,01$ & $0,40 \pm 0,05$ & $3,90 \pm 0,10$ & $2,58 \pm 0,11$ & $4,26 \pm 0,01$ \\
\hline BS7.1 & $3,74 \pm 0,01$ & $0,42 \pm 0,01$ & $6,55 \pm 0,15$ & $7,08 \pm 0,11$ & $1,82 \pm 0,01$ \\
\hline BS5 & $3,50 \pm 0,00$ & $0,52 \pm 0,01$ & $7,10 \pm 0,20$ & $5,23 \pm 0,08$ & $4,70 \pm 0,12$ \\
\hline Mean values & $3,66 \pm 0,01$ & $0,43 \pm 0,02$ & $3,95 \pm 0,15$ & $4,88 \pm 14$ & $3,80 \pm 0,03$ \\
\hline
\end{tabular}

The work of Ouoba et al. (2012) on palm wine from Borassus akeassii have shown a pH between 3.48 and 4.12 . These values are similar to those we obtained with samples of fermented sap. Tapsoba et al. (2011) also found a pH between 3.6 and 4.5. The values of total acidity and alcohol levels in our samples of fermented sap are similar to those found by Santiago and Ruíz-Terán (2014) who obtained an alcohol content between 1 and $6 \%$ (v/v) and an acidity ranging from 0.1 to $0.5 \%$ (w/v). Tapsoba et al. (2014) showed an alcohol content of $5.80 \pm 2.13$ and $4.7 \pm$ $1.47 \%(\mathrm{v} / \mathrm{v})$ and a total acidity of $0.64 \pm 0.08$ and $0.82 \pm 0.29 \%(\mathrm{w} / \mathrm{v})$. These results could be due to the initial physico-chemical composition of the sap and the nature of fermentation. In view of the physical and chemical characteristics, the fresh sap has good nutritional quality while fermented sap has a fairly good nutritional quality because of its acidity.

Table 7:- Physico-chemical parameters of $48 \mathrm{~h}$ fermented palm sap

\begin{tabular}{|c|c|c|c|c|c|}
\hline \multirow[b]{2}{*}{ Samples } & \multicolumn{5}{|c|}{ Physico-chemical parameters } \\
\hline & $\mathrm{pH}$ & $\begin{array}{c}\text { Total acidity } \\
\% \mathrm{w} / \mathrm{v}\end{array}$ & $\begin{array}{l}\text { Sugars } \\
\% \mathrm{w} / \mathrm{v}\end{array}$ & $\begin{array}{c}\text { Vitamin C } \\
\% / \mathrm{w} / \mathrm{v}\end{array}$ & $\begin{array}{c}\text { Alcohol content } \\
\% \mathrm{v} / \mathrm{v}\end{array}$ \\
\hline S5 & $3,35 \pm 0,01$ & $0,70 \pm 0,04$ & $2,15 \pm 0,05$ & $2,24 \pm 0,22$ & $4,58 \pm 0,01$ \\
\hline S6 & $3,50 \pm 0,05$ & $0,43 \pm 0,01$ & $1,50 \pm 0,00$ & $4,38 \pm 0,11$ & $4,82 \pm 0,02$ \\
\hline S7 & $3,45 \pm 0,05$ & $0,55 \pm 0,01$ & $2,05 \pm 0,05$ & $1,68 \pm 0,11$ & $4,48 \pm 0,01$ \\
\hline S8 & $3,40 \pm 0,00$ & $0,66 \pm 0,01$ & $1,80 \pm 0,00$ & $3,48 \pm 0,11$ & $5,69 \pm 0,04$ \\
\hline S1.1 & $3,25 \pm 0,01$ & $0,76 \pm 0,01$ & $2,25 \pm 0,05$ & $1,80 \pm 0,00$ & $4,56 \pm 0,02$ \\
\hline S1.2 & $3,51 \pm 0,01$ & $0,56 \pm 0,01$ & $1,10 \pm 0,10$ & $1,34 \pm 0,22$ & $5,87 \pm 0,01$ \\
\hline S1.3 & $3,35 \pm 0,03$ & $0,56 \pm 0,03$ & $2,35 \pm 0,05$ & $3,26 \pm 0,11$ & $4,04 \pm 0,06$ \\
\hline S1.4 & $3,50 \pm 0,00$ & $0,50 \pm 0,03$ & $2,40 \pm 0,10$ & $1,79 \pm 0,22$ & $5,95 \pm 0,01$ \\
\hline S6.1 & $3,40 \pm 0,01$ & $0,48 \pm 0,01$ & $0,75 \pm 0,05$ & $1,42 \pm 0,02$ & $3,53 \pm 0,03$ \\
\hline S7.1 & $3,27 \pm 0,04$ & $0,72 \pm 0,01$ & $0,55 \pm 0,05$ & $0,78 \pm 0,06$ & $6,13 \pm 0,01$ \\
\hline Mean values & $3,40 \pm 0,02$ & $0,59 \pm 0,02$ & $1,69 \pm 0,05$ & $2,22 \pm 0,12$ & $4,96 \pm 0,02$ \\
\hline
\end{tabular}

\section{Conclusion:-}

This study allowed to evaluate the microbiological and physico-chemical quality of the sap collected from Borassus akeassii. The microbiological analysis results show contamination of the fresh sap by coliforms, strains of Staphylococcus aureus and Salmonella sp. The presence of these pathogens responsible for foodborne illness can be a risk to consumer health. However, no pathogen was found in the fermented palmyra sap for 24 hours and 48 hours' time. The physicochemical analyzes revealed that the fresh sap contain large amounts of sugars and vitamin $\mathrm{C}$ than fermented sap. Fermentation appears as a means of improving the quality of the boxwood wine through the inhibition of pathogens. However, the acidity of the fermented sap causes loss of its organoleptic quality, making it undesirable to consumers. Fermented sap for 24 hours would be recommended for consumption. Good practices of production and hygiene are needed to be implemented during collection for quality improvement.

\section{References:-}


1. Adedayo, M. R. and Ajiboye, A. E. (2011): Antimicrobial property of palm wine. Int. Res. J. Microbiol., 2: 265269.

2. Aidoo, K.E., Nout, M.J.R. and Sarkar, P.K. (2006): Occurrence and function of yeasts in Asian indigenous fermented foods. FEMS Yeasts Res., 6: 30-39.

3. Akinrotoye, K. P. (2014): Effects of fermented palm wine on some diarrhoeagenic bacteria. Elite Res. J. Biotechnol. Microbiol., 2: 4-14.

4. Alcántara-Hernández, R.J., Rodríguez-Álvarez, J.A., Valenzuela-Encinas, F. A., Gutiérrez-Miceli, F. A., Castañón-González, H., Marsch, R., Ayora-Talavera, T. and Dendooven, L. (2010): The bacterial community in "taberna" a traditional beverage of Southern Mexico. Lett. Appl. Microbiol., 51: 558-563.

5. Amoa-awua, W.K., Sampson, E. and Tano-Debrah, K. (2007): Growth of yeasts, lactic and acetic acid bacteria in palm wine during tapping and fermentation from felled oil palm (Elaeis guineensis) in Ghana. J. Appl. Microbiol., 102: 599-606.

6. AOAC (1990): Official Methods of Analysis of the Association of Official Analytical Chemists, 15th ed., Vol. 2. Washington, DC: AOAC.

7. AOAC (2000): Official Methods of Analysis of the Association of Official Analytical Chemists, 17th ed., Vol. 2. Washington, DC: AOAC.

8. Atputharajah, J. D., Widanapathirana, S. and Samarajeewa, U. (1986): Microbiology and biochemistry of natural fermentation of coconut palm sap. Food Microbiol., 3: 273-280.

9. Bassir, O. (1968): Some Nigerian wines. West Afr. J. Biol. Appl. Chem., 10: 42-45.

10. Bayton, R. P., Ouedraogo, A. and Guinko, S. (2006): The genus Borassus (Arecaceae) in West Africa, with a description of a new species from Burkina Faso. Bota. J. Linn. Soc., 419-427.

11. Bayton, R.P. and Ouédraogo, A. (2009): Discovering Africa's Newest Palm (Borassus akeassii). PALMS, 53: 37-45.

12. Combet-Blanc, Y. (1997) : Caractérisation physiologique d'une nouvelle bactérie lactique thermophile, Bacillus thermoamylovorance, isolée du vin de palme. Thèse. p. 163. Université de Provence, Aix-Marseille.

13. Dalibard, C. (1999): Overall view on the tradition of tapping palm trees and prospects for animal production. Livest. Res. Rural. Dev., 11: 6-10.

14. Debmalya, B. and Mazumdar, B.C. (2008): Comparative nutritive values of palm saps before and after their partial fermentation and effective use of wild date (Phoenix sylvestris Roxb.) sap in treatment of anemia. Res. J. Medi. Medic. Scie., 3: 173-176.

15. Dioha, I.J., Olugbemi, O., Odin, E.M. and Eneji, M. A. (2009): Zero additives preservation of Raphia palm wine. Int. J. Biol. Chem. Scie., 3: 1258-1264.

16. Essiamah, S.K. (1983): Utilization of palms in West Africa (Forest products). Die Nutzung der Palmen in Westafrika. Forstarchiv, 54: 232-236.

17. Heller, R. (1981). Réactions obscures et synthèses carbonées. Abrégé de physiologie Végétale, Nutrition. In Masson, 1: 183-205.

18. ISO 7218 (2007) : Microbiologie des denrées alimentaires et aliments pour animaux. Règles générales rélatives aux analyses microbiologiques. Third edition, $74 \mathrm{p}$.

19. Kadere, T., Miyamoto, T., Oniang'o, R. K., Kutina, P. M. and Njoroge, S. M. (2008): Isolation and identification of the genera Acetobacter and Gluconobacter in coconut toddy (mnazi). Afr. J. Biotechnol., 7: 2963-2971.

20. Malonga, A., Mavoungou, O., Kobawila, S.C. and Louembe, D. (1995): Etude microbiologique et biochimique du vin de palme (Elaesis Guineensis Jacq) en République du Congo. Microbiol. Alim. Nutri. 13: 195-200.

21. Miège, J. (1985): Palmales. Int. J. Bers., 13: 764-767.

22. Mollet, M., Herzog, F., Behi, Y.E.N. and Farah, Z. (2000): Sustainable exploitation of Borassus aethiopum, Elaeis guineensis and Raphia hookeri for the extraction of palm wine in Cote d'Ivoire. Environ. Dev. Sustain., 2: 45-59.

23. Naknean, P., Meenune, M. and Roudaut, G. (2010): Characterization of palm sap harvested in Songkhla province, Southern Thailand. Int. Food Res. J., 17: 977-986.

24. Noll, R.G. (2008): The wines of West Africa: History, technology and tasting notes. J. Wine Econ., 3: 85-94.

25. Obi, C.N., Ogbulie, J.N. and Nkwo, A.M. (2015): Assessment of microbial growth and survival in fresh rafia palmwine from Umuariaga community, Ikwuano L. G. A. Abia State, Nigeria. Int. J. Curr. Microbiol. Appl. Scie., 4: 484-494.

26. Ogbulie, T.E., Ogbulie, J.N. and Njoku, H.O. (2007): Comparative study on the microbiology and shelf life stability of palm wine from Elaeis guineensis and Raphia hookeri obtained from Okigwe, Nigria. Afr. J. Biotechnol., 6: 914-922. 
27. Okafor, N. (1972): Microbiology of Nigerian palm wine with particular reference to bacteria. J. Appl. Bacteriol., 38: 81-88.

28. Okafor, N. (1975): Preliminary microbiological studies on the preservation of palm wine. J. Appl. Bacteriol., 43: 159-161.

29. Okafor, N. (1978): Microbiology and Biochemistry of oil palm wine. Advan. Appl. Microbiol., 24: 237-256.

30. Olawale, A.K., Akintobi, A.O. and David, O.M. (2010): Evaluation of microbial quality and alcoholic improvement of natural and fermented Raphia Palm wine ("Ogoro"). New York Scie. J., 3: 35-39.

31. Ouoba, L.I.I., Kando, C., Parkouda, C., Sawadogo-Lingani, H., Diawara, B. and Sutherland, J.P. (2012): The microbiology of Bandji, palm wine of Borassus akeassii from Burkina Faso: identification and genotypic diversity of yeasts, lactic acid and acetic acid bacteria. J. Appl. Microbiol., 113: 1428-1441.

32. Sambou, B., Goudiaby, A., Ervik, F., Diallo, D. and Camara, C. (2002): Palm wine harvesting by the Bassari threatens Borassus aethiopum populations in north-western Guinea. Biodiv. Cons., 11: 1149-1161.

33. Santiago-Urbina, J.A. and Ruíz-Terán, F. (2014): Microbiology and biochemistry of traditional palm wine produced around the world. Int. Food Res. J., 21: 1261-1269.

34. Santiago-Urbina, J.A., Verdugo-Valdez, A.G. and Ruíz-Terán, F. (2013): Physicochemical and microbiological changes during tapping of palm sap to produce an alcoholic beverage called "Taberna", which is produced in the south east of Mexico. Food Contr., 33: 58-62.

35. Sekar, S. and Mariappan, S. (2005): Usage of traditional fermented products by Indian rural folks and IPR. Indi. J. Tradi. Know. 6: 111-120.

36. Stringini, M., Comitini, F., Taccari, M. and Ciani, M. (2009): Yeast diversity during tapping and fermentation of palm wine from Cameroon. Food Microbiol., 26: 415- 420.

37. Swings, J. and De Ley, J., (1977): The biology of Zymomonas. Ameri. J. Bacteriol. Rev., 41: 1-46.

38. Tapsoba, F., Savadogo, A., Somda, K.M., Zongo, C., Barro, N. and Traoré, S.A. (2011): Biodiversité microbienne et paramètres physico-chimiques de quelques vins de rônier (Borassus akeassii) produits traditionnellement au Burkina Faso. Rev. Microbiol. Indust. Sanit. Environ., 5: 1-22.

39. Tapsoba, F., Savadogo, A., Zongo, C. and Traoré, A.S. (2014): Impact of technological diagram on biochemical and microbiological quality of Borassus akeassii wine produced traditionally in Burkina Faso. Amer. J. Food Scie. Technol., 2: 179-186.

40. Tiépma, N.E.F., Zambou, N.F., Agbor, E. and Tchouanguep, M.F. (2013): Physicochemical changes of raffia sap (Raphia mambillensis) contents during spontaneous fermentation. Afr. J. Biotechnol., 12: 6013-6018.

41. Van Pee, Y. and Swings, J.G. (1971): Chemical and microbiological studies on Congolese palm wine (Elaies gineensis). East Afr. Agri. Fores. J., 36: 311-314.

42. Ziadi, M., M'hir, S., Kbaier, N., Hamdi, M. and Ferchichi, A. (2011): Microbiological analysis and screening of lactic acid bacteria from Tunisian date palm sap. Afr. J. Microbiol. Res., 5: 2929-2935. 